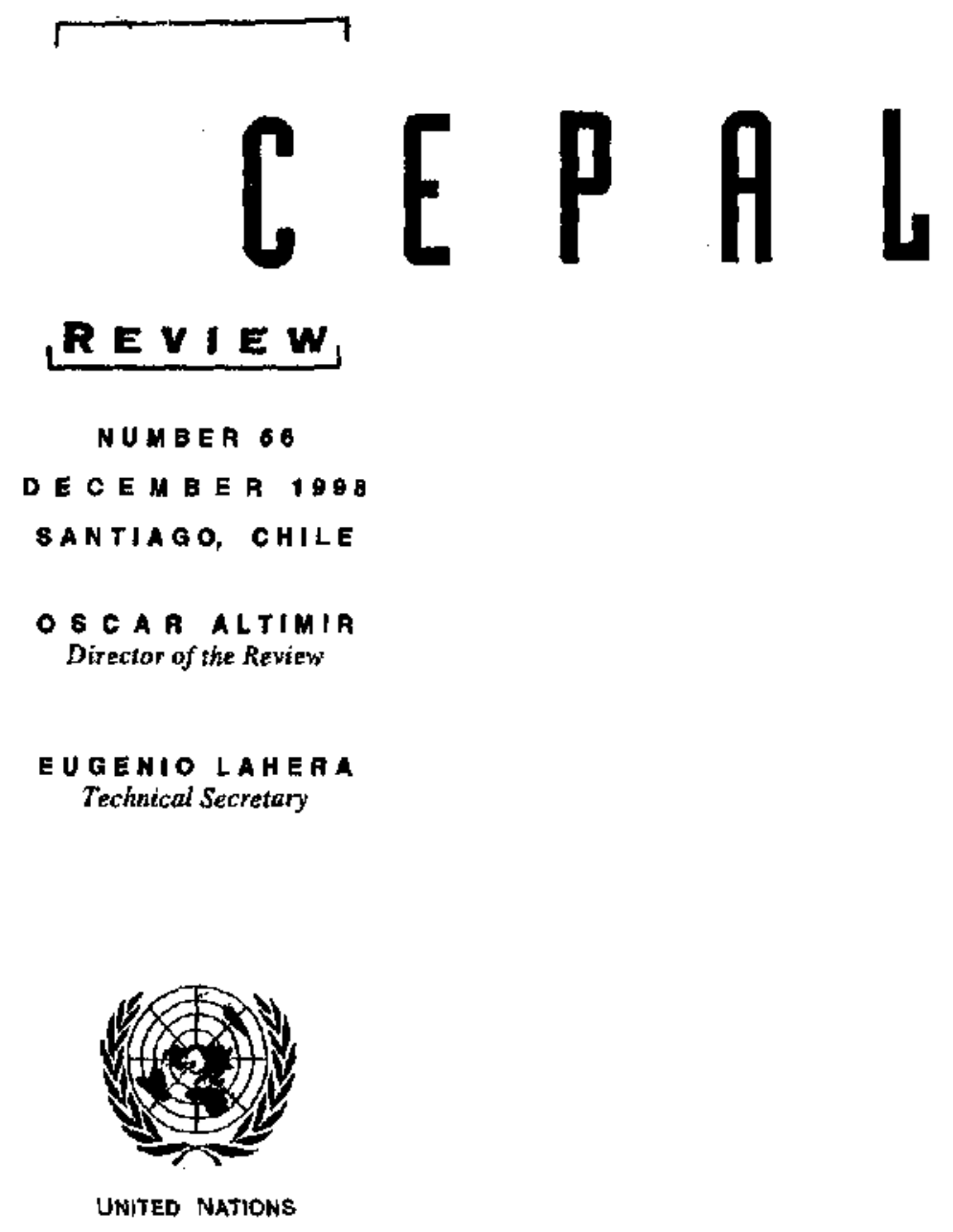


CONTENTS

Beyond the Washington Consensus: an ECLAC perspectlve

José Antonio Ocampo

The Cuban economy

David Ibarra and Jorge Máttar

Education in Latin America: demand and distribution are factors that matter

Nancy Birdsall, Juan Luis Londoño and Lesley O'Connell

Determinants of inequality among urban households

Luis Felipe Jiménez $L$, and Nora Ruedi $A$.

Health management contracts in Costa Alca from a comparative perspective

Ana Sojo

A development strategy tounded on natural resource-based production clusters

Jaseph Ramos

Blg Latin American industrial companies and groups

Celso Garrido and Wilson Peres

Between political control and efflciency gains:

the evolution of agrarian property rights in Mexico

Gustavo Gordillo, Alain de Janvry and Elizabeth Sadoulet

Tariffs and the Plano Real in Brazil

Renaso Baumann, Josefina Rivero and Yohana Zavattiero 


\section{Education in Latin America: demand and distribution are factors that matter}

\section{Nancy BIrdsall \\ Principal Associate, Carnegie Endowment for International Peace. \\ Juen Luis Londońo \\ President, Revista Dinero (Colombia).}

\section{Lestey O'Connell}

Consuitant, Inter-American Development Bank.
Although the governments of the region have increased their spending on health and education, the results have been unsatisfactory. Expenditure on these services has traditionally been considered as a transfer rather than an investment. The accumulation of human capital has been relatively slow, with negative effects on economic growth, and it has been distributed unevenly among the different income groups, thereby further increasing inequality. This article analyses the causes of these results. First it describes the nature of the problem, presenting data which confirm the scanty and inequitable accumulation of social capital in the region, which bas further accentuated the inequitable distribution of wealth and income. It then discusses the causes of these resuits, emphasizing the effect of the weak demand for education among the poor, due, among other reasons, to income constraints and the ald policy of economic protection. Among its conclusions, it lays emphasis on the fact that the economic reforms have increased the demand for social capital, thus raising the private retums on investment in human capital and giving rise to renewed interest within the private sector in improving the public educational system. The public sector also has new incentives to embark on the reform of the health and education sectors. This could set up a virtuous circle of better accumulation and distribution of human capital, linked with more equitable economic growth. 


\section{I}

\section{Introduction}

The early postwar development model emphasized a strong role for the State. The challenge of coordination, of ensuring the complementary public and private investment in industry, transport and communications needed to jump-start an economy, seemed to justify the State not only assuming a leading role as planner, but also taking the commanding heights of the economy and managing production. In this early development model, spending on such "nonproductive sectors" as health and education was seen as a drain on the accumulation of productive assets, and thus as a cost in terms of growth. Early demographic models, fot example, emphasized that rapid population growth in developing countries was draining away public resources on schooling and health services, thus reducing the availability of productive physical capital per capita.

The newer growth models introduced the concept of "human capital" as a productive investment. In the new classical growth models, human capital accumulation is as critical to the growth process as the previous narrow concept of physical capital: growth is stimulated by increasing savings and investment in education. The recent endogenous growth models attribute an even stronger role to human capital. In these models, sustainable growth is a result, in part, of the positive externalities generated by education, an important form of human capital; new ideas and new technologies are critical to high sustained growth, and their generation, in turn, depends on high levels of human capital.

The newer growth models provide an elegant and compelling justification for human capital investments as efficient and growth-enhancing. In their simplest form, however (as reflected in the wellknown empirical studies of growth by Barro, Sala-iMartin, Romer and others), they embody assumptions which are poor guides to policy choices.

First, and most fundamental for this article, the distribution of human capital across individuals is ignored. The implicit assumption is that the accumulation process will "trickle-down" and benefit members of all income groups proportionately.
Second, and reinforcing the first shortcoming, demand is ignored. Human capital accumulation is treated as exogenous. The determinants of the accumulation process -household decisions to invest in human capital, and public policy decisions about the size and allocation of similar investments- are not modelled. The initial distribution of adult education across households, which is critical to investments in children's education (Schultz, 1988), and the macroeconomic, trade and other economy-wide policies that also affect household demand by different income groups for education, are not explicitly considered. This ignores the fact that parents who are poorer and less educated are likely to invest less in their children's education.

And third, the problem of delivery -the efficient and equitable production of social services- is also ignored. A major role for the State in the delivery of health and education services is implicitly endorsed. The emphasis on the positive externalities of human capital in new growth models is based on the logic of a market failure, particularly in capital markets, which inhibits optimal private investment. Because human capital cannot be appropriated, borrowers cannot use future human capital as collateral; even when agents recognize high returns to private investments in health and schooling, they cannot borrow and their investments are therefore liquidity-constrained. Thus in these models the role of the State is critical, reinforcing the traditional view of government as the major financier, producer and provider of all social services.'

This lack of emphasis on the distribution, demand for, and delivery of social programmes has reinforced the long-standing assumption that Latin America's developing societies face an inevitable tradeoff between efficiency and faimess. In the tradition of Kuznets, analysts have tended to view the high and growing income inequality of the region as

\footnotetext{
1 of course, the State can play a strong role in the selective financing of social programmes, apart from their provision. On this particular issue, the new growth models are silent.
} 
an inevitable consequence of economic development. Past efforts of governments to rectify unfairness using populist transfers - with disastrous fiscal resultshave reinforced the pessimistic view that Latin America cannot enjoy growth with equity. Given that pessimism, the range of recommended policy responses has been comparatively unambitious: a remedial and marginal social policy designed to cushion the impact of increasing poverty, without any emphasis on investment in the human capital of the poor.

In challenging the assumptions of the new growth models and of the tradeoff pessimists, the present article focusses on the social sectors -education and health- in Latin America. The process of investment in these sectors m-that is to say, investment in human capital- has not worked well in the region. Though governments have committed as many or more resources to health and education services as have other developing countries, the region has a poor record, given its income. Spending on these services, particularly for the poor, has historically been viewed as a transfer rather than an investment. Human capital accumulation has been relatively slow, with negative effects on growth, and it has been highly unequal across income groups, exacerbating income inequality.

This article examines why. The discussion is based on a broader consideration of the points made above, focussing on the interrelated issues of demand (for education, for example) and distribution. A thorough discussion of the third point (the transformation of social service delivery) may be found in Birdsall and Londoño (1998).

First, with regard to demand, the low accumulation of human capital in Latin America reflects low household demand for education, particularly among the poor. Second, with regand to distribution, this low household demand for human capital reflects the high proportion of poor households in Latin America and the depth of their poverty. The historically unequal access of the poor to income-producing assets (land as well as human capital) in the region helps to explain the vicious cycle of low accumulation of human capital and widespread poverty. Moreover, low accumulation of human capital by the poor has been exacerbated by regressive patterns of public spending on social programmes the poor have not benefitted much from public spending on education and health services- and by economic policies that have penal- ized labour and discouraged household investment in education.

In short, the trickle-down approach to human capital accumulation in Latin America has failed. If the region's economies are to exploit the efficiency and growth-enhancing effects of more rapid human capital accumulation, there will need to be more emphasis on equity in the distribution of the services that generate such capital. ${ }^{2}$

Section II of this article describes the nature of the challenge, summarizing evidence which shows that, despite adequate public spending, accumulation of human capital in Latin America has been low and inequitable -the distribution of education has hardly improved over time. Empirical analysis shows that low and unequal human capital accumulation in Latin America goes a long way towards explaining not only Latin America's high level of income disparity and poverty but also its sluggish capital formation and lack of economic growth, and that, in a vicious circle, the insufficiency and inequality of the region's human capital has reflected, and at the same time reinforced, the high degree of asset and income inequality throughout Latin America.

In section III, the underlying reasons for low and unequal human capital accumulation are discussed, emphasizing the effect of weak demand for education among the poor due to liquidity constraints and the likelihood of low returns to human capital investment in economies biased against labour. On the one hand, history suggests a discouraging vicious circle, in which initial poverty and income inequality have led to slow and unequal human capital accumulation, which has in turn reduced growth and exacerbated inequality. On the other hand, there is a positive implication: more rapid accumulation, with greater emphasis on equal access to education, ' can both speed economic growth and reciuce income inequality. More and more equal education can enhance both efficiency and equity.

The article ends on a note of optimism. Recent economy-wide reforms are increasing the demand for skilled labour in the region. This is raising the private return to human capital investment, and generating a

\footnotetext{
2 In Birdsall and Londoño (1998) we address the challenge of more equitable social service delivery by advocating a new "horizontal" approach to the provision of social services: one which relies on greater targeting of public spending to the poor, nore competitive supply of services, and an emphasis on demand that empowers consumers, including poor consumers.
} 
new round of interest in the business sector for an improved public system of education. At the same time, success on the macroeconomic front has created a readiness in the public sector to address the challenges of reforming the education and health sectors -education was a major focus of attention for the Heads of State at the 1998 Summit of the Americas in Santiago, Chile. Throughout the region, there are a growing number of efforts to test new approaches to the delivery of social services that combine centrally determined rules of the game with market-led competitive supply and consumer empowerment. These efforts show the potential for greater internal efficiency in the delivery of social programmes and more responsiveness and accountability of public systems to the needs of the poor. More access by the poor to good education and health services can set in motion a new, virtuous circle that includes fairer distribution of assets and opportunities, faster economic growth and wider distribution of its benefits.

\section{II}

\section{Low and unequal human capital}

\section{accumulation in Latin America}

First the facts. After taking account of its per capita income, Latin America's performance in human capital accumulation is weak compared to other regions. This is particularly true for education: average schooling attainment is two years below what would be expected from the level of per capita income: a record barely better than that of sub-Saharan Africa and well below that of East and Southeast Asia. At the beginning of the $1990 \mathrm{~s}$, workers had an average of 5.2 years of education -nearly a third less than would be expected for countries with the region's level of development- and more than a third of the children entering primary school were not finishing it: over twice the rate of other regions in the world.

The education gap has worsened over the last three decades. At the start of the 1970s, Latin America had a low level of education, lower than the countries of Europe and Southeast Asia with comparable income levels but no different from the rest of the developing world, once adjusted on a per capita basis. Since then, however, education in Latin America (led by Brazil, Mexico, Venezuela and Central America) has grown at a positive but slow rate, well below the growth achieved by the Asian countries and the rest of the developing world. In 1980, the region's work force lagged behind the average for the developing world, in terms of number of years of education, by an average of one year, and by the mid-1990s this figure had doubled. Compared to East and Southeast Asia, Latin America's lag in education has increased from less than one year in 1970 to about 4 years in 1995 (figure l).
The shortfall in health compared with other regions is not so marked. Average life expectancy is about two years below the level that should be expected, given the region's income (figure 2). This result is perhaps due to a smaller gender gap in education than elsewhere, the positive effect of mothers' educational levels on infant mortality, and relatively greater spending and innovation in the health sector in Latin America (IDB, 1996).

The primary problem is not one of low public expenditure on heaith and education; such expenditure is similar to that of other developing regions, at $6.6 \%$ of GDP (table 1) ${ }^{3}$ Rather, the problem has been the inefficient use of public expenditure and the unequal incidence of public spending on these services: that is to say, the relatively low proportion of public spending that has benefitted the poor. ${ }^{4}$ Compared to

\footnotetext{
${ }^{3}$ Consistent with performance, spending is relatively greater on health than on education, compared to other regions. In this article, education is emphasized as the measure of human capital accumulation. Health and other measures also reflect investment in human capital, of course, but in a less linear manner and thus with less easity measured and differentiated effects on productivity and income growth.

${ }^{4}$ Compared with East Asia, low economic growth and the later decline in fertility also translated into lower spending per child in Latin America, especially in the 1980s. Now, however, Latin America is beginning to benefit from a reduction in the growth of school-age populations and from the higher absolute spending per capita that is associated with higher rates of economic growth, even without increases in the proportion of GDP going to social spending. In addition, many countries are in fact increasing that proportion.
} 
FIGURB |

\section{Latin Amarka and East Asla:}

The educational defleit

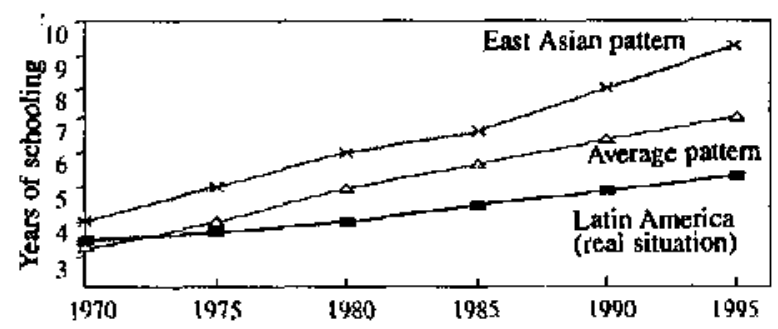

Source: Inter-American Development Bank, Economic and social progress in Latin America, Washington, D. C., 1996

FIGURE 2

Latin America: The Ifie expectancy deflcit

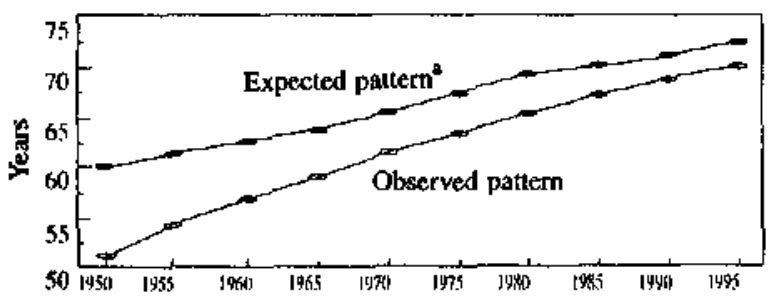

Source: Inter-American Developnent Bank, Economic and social progress in Latin America, Washington, D. C., 1996.

a Calculated from the equation $e(\ln (y)$, time).

TABLE 1

Social expenditure in the 1990s

(\% of GDP)

\begin{tabular}{|c|c|c|c|c|}
\hline & \multicolumn{3}{|c|}{ Public expenditure } & \multirow{2}{*}{$\begin{array}{c}\text { Privale } \\
\text { expendi- } \\
\text { nure } \\
\text { Health }\end{array}$} \\
\hline & Tolal & Education & Health & \\
\hline Latin America & 6.6 & 3.6 & 3.0 & 3.1 \\
\hline $\begin{array}{l}\text { Other developing } \\
\text { countries }\end{array}$ & 6.4 & 4.2 & 2.2 & 1.9 \\
\hline $\begin{array}{l}\text { All developing } \\
\text { countries }\end{array}$ & 6.5 & 4.1 & 2.4 & 2.2 \\
\hline Worldwide & 99 & 5.1 & 4.8 & 3.2 \\
\hline
\end{tabular}

Source: Inter-American Development Bank (IDB), Economic and Social Progress in Lain America, Washington, D C., 1996.
East Asia and the industrialized countries, Latin America displays high inequality of human capital (its inequality in the distribution of land, another critical productive asset, is the highest of any region -see figures 3 and 4). ${ }^{5}$ Thus, the low rate of overall accumulation the average between the sizeable increases in the number of years of schooling completed for a small number of the people and very limited increases for the great majority- is due in part to the unequal nature of the accumulation."

Moreover, contrary to what might be expected, the increase in average years of schooling in Latin America over the last three decades has not been associated with an improvement in the distribution of education. Figure 5 contrasts the virtually unchanged distribution of education in Latin America to the improvement in East Asia over this period. ${ }^{7}$

\footnotetext{
SIn figures 3 and 4 , years of schooling are estimaled using Barro-Lee's frequency distribution for the population 25 years and over within categories of education; i.e., no schooling, incomplete primary schooling, completed primary schooling, incomplete secondary schooling, completed secondary schooling, incomplete higher education, and completed higher education). There is some evidence that inequality of education is beginning to decline in Latin America: in 1990, inequality was lower for young adults (aged 20-30) than for older groups (Elizabeth King, personal correspondence, June 1997). However, the experience of countries like Indonesia shows that even starting from a low level, rapid accumulation can be accompanied by im. proved distribution.

${ }^{6}$ Low accumulation in Latin America is strongly associated with the low quality of public primary and secondary schools, as described and discussed in Schiefelbein, 1995 and Birdsall, 1998. Among a multitude of systemic problems in highly centralized systems is the difficulty of recruiting and retaining the best possible teachers. In many countries, teachers are poorly paid; moreover, tenchers (including those with the least training) are poorly supported, but nevertheless automatically advance through the system, often persisting in unsatisfactory working conditions in order to benefit from guaranteed pensions and retirement as early as at age 50. Many countries' budgets are burdened with non-working teachers, some actually retired or even "phantom" teachers, straining the resoutces available for genuine working teachers. The challenge remains for governments in the region to create : mechanisms to bring teachers' unions, some of which are politicized and resist change, into a relationship of collaboration and cooperation.

${ }^{7}$ It is normal that existing disparities in human capital of the population will widen as educational systems initially expand, until average schooling reaches five to six years (Londono and
} Székely, 1997). 
FIGURE 3

Inequality of asset diatrlbution, cIrca 1990

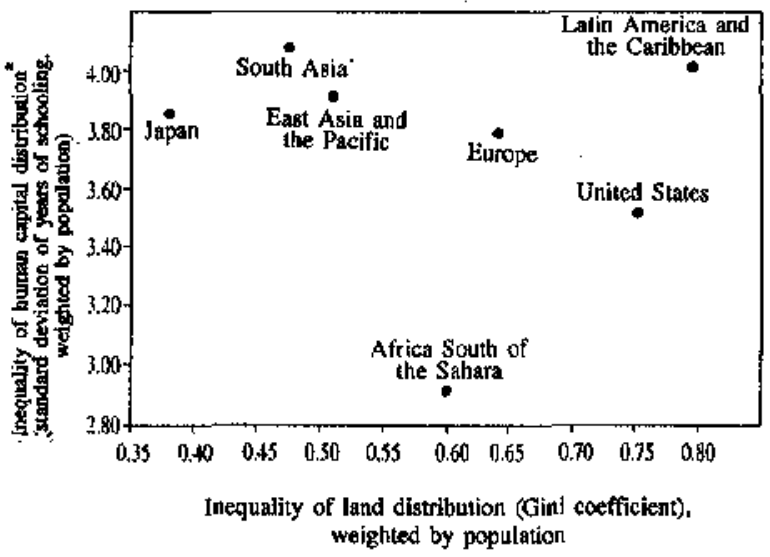

Source: The inequality of human capital distribution was calculated on the basis of figures for education taken from R.J. Barto and I. Lee, Intemational Comparison of Educational Attainment, Washington, D. C., World Bank, 1993. The Gini coefficients for land distribution were obtained from K. Deininger and L. Squire (personal correspondence).

The measure of inequality of human capital distribution is the standard deviation of the number of years of schooling of the population aged 25 or more (see footnote 5 ).

FIGURE 5

Latin America and the Carlbbean and East Asia: Inequality of human capltal distribution (reglonal comparison) a

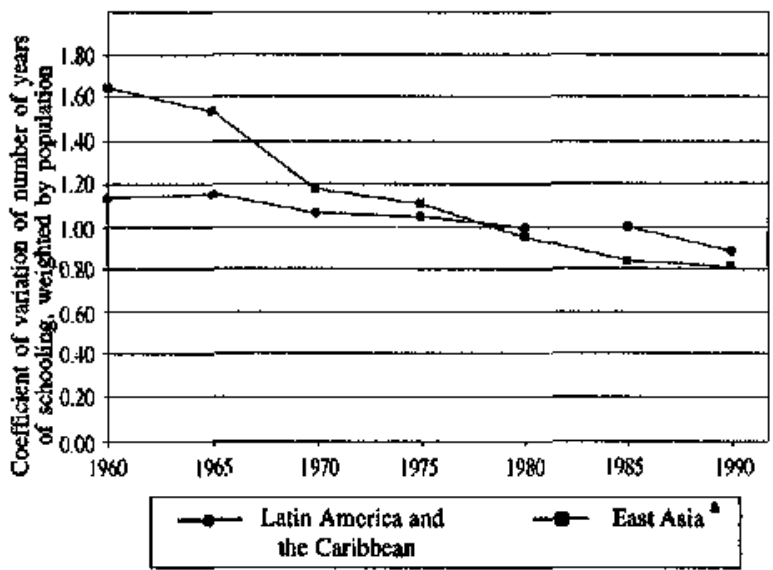

Source: The inequality of human capital distribution was calculated on the basis of information taken from R. J. Barro and J. Lee, Intemational Comparisons in Educational Attainment, Washington, D. C., World Bank, 1993.

a East Asia comprises Hong Kong, Indonesia, South Korea, Malaysia, Singapore, Taiwan and Thailand. In this figure, the inequality of distribution of human capital is measured by the coefficient of variation of the number of years of schooling.
FGURE 4

Inequality of asset distrlbution, circa 1990

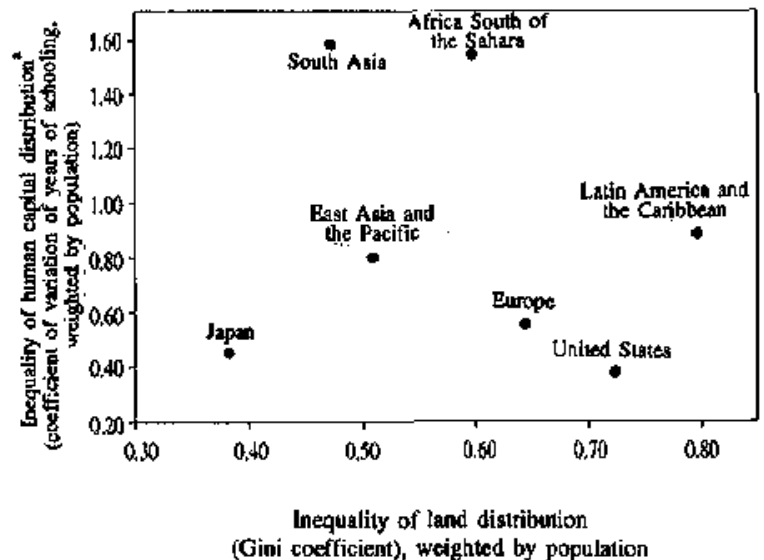

Source: The inequality of human capital distribution was calculated on the basis of figures for education taken from R. J. Barro and J. Lee. Intemational Comparison of Edtcational Anainment, Washington, D. C., World Bank, 1993. The Gini coefficients for land distribution were obtained from K. Deininger and $\mathbf{L}$. Squire (personal correspondence).

a In this figure, the measure of inequality of human capital distribution is the coefficient of variation: i.e., the quotient of the standard deviation and the mean. This measure takes acount of the effect of changes in the average number of years of schooling on the distribution (see footnote 5). It may be noted that in this figure the high inequality of human capital in Latin America (see figure 3) goes down compared with other regions when the standard deviation of the number of years of schooling of adults is divided by the mean schooling of adults. The relatively high level of schooling in Latin America compared with other developing countries is not sufficient, however, to make up for the high standard deviation for a given mean compared with East Asia and the developed regions.

\section{Effects of low and unequal accumulation on growth}

What have been the effects of low and unequal human capital accumulation on the growth rate in Latin America over the last three decades? Table 2 shows the results of estimating a traditional growth equation across countries, using the best recently available data on the distribution of income (Deininger and Squire, 1996). For these estimates, the countries selected were those for which Lorenz curves were available for two periods of time separated by at least five years, with income estimates per capita in international purchasing power prices, and with data on physical capital investment, the education of the la- 


\begin{tabular}{|c|c|c|c|}
\hline $\begin{array}{l}\text { A. Explaining aggregate growth } \\
\text { Independent variable }\end{array}$ & (1) & (2) & (3) \\
\hline Constant & $0.0 \mathrm{t}$ & $0.04^{\mathrm{a}}$ & 0.03 \\
\hline Capital accumulation & $0.53^{\mathrm{a}}$ & $0.57^{\mathrm{n}}$ & $0.54^{\prime \prime}$ \\
\hline \multicolumn{4}{|l|}{ Initial conditions: } \\
\hline Income level & -0.88 & -0.41 & -0.42 \\
\hline Education level & 0.17 & $0.28^{b}$ & $0.30^{\mathrm{b}}$ \\
\hline Income inequality & $-0.05^{b}$ & -0.03 & -0.002 \\
\hline Land inequality & & $-0.02^{b}$ & -0.01 \\
\hline Educational inequality & & $-0.09^{\mathrm{b}}$ & $-0.09^{\mathrm{b}}$ \\
\hline Natural resources & & $:$ & -0.01 \\
\hline \multicolumn{4}{|l|}{ Changes in: } \\
\hline Income inequality & & $\vdots$ & \\
\hline Trade openness & & : & 0.02 \\
\hline Manufacturing trade & & & \\
\hline \multicolumn{4}{|l|}{ Primary trade } \\
\hline Dummy for Latin America and the Caribbean & & & 0.0704 \\
\hline $\mathrm{R}^{2}$ & 0.61 & 0.70 & 0.76 \\
\hline \multicolumn{4}{|l|}{ B. Explaining income growth of the poorest } \\
\hline Independent variable & (4) & (5) & (6) \\
\hline Constant & 0.00 & $0.05^{\mathrm{e}}$ & $0.04^{\mathrm{c}}$ \\
\hline Aggregate growth & $1.31^{\mathrm{s}}$ & & \\
\hline Capital accumulation & & $0.72^{2}$ & $0.77^{\mathrm{a}}$ \\
\hline \multicolumn{4}{|l|}{ Initial conditions: } \\
\hline Income level & & & \\
\hline Education level & & $0.41^{c}$ & $0.5 t^{8}$ \\
\hline Income inequality & & 0.05 & 0.02 \\
\hline L.and inequality & & $-0.07^{b}$ & -0.02 \\
\hline Educational inequality & & $-0.20^{\mathrm{t}}$ & $-0.18^{b}$ \\
\hline Natural resources & & & \\
\hline \multicolumn{4}{|l|}{ Changes in: } \\
\hline Income incquality & & & $-0.27^{3}$ \\
\hline Trade opentiess & & & \\
\hline Manufacturing trade & & & $0.05^{\mathfrak{c}}$ \\
\hline Primary trade & & & -0.01 \\
\hline Dummy variable for Latin America and the Caribbean & & & -0.01 \\
\hline $\mathrm{R}^{2}$ & 0.51 & 0.42 & 0.63 \\
\hline
\end{tabular}

Source: N. Birdsall and I. L. Londonto, Asset inequality raatters: an assessment of the World Bank's approach to poverty reduction, The American Economic Review, vol. 87, No. 2, Nashvilie, TN, American Economic Association, 1997.

${ }^{a}$ Statistically significant at the ?-percent level.

Statistically significant at the 5-percent level.

"Values statistically significant at the 10 -percent level.

bour force (which was used to construct the measure of human capital distribution), land distribution and trade indicators.

The findings (reported originally in Birdsail and Londoño, 1997) are straightforward with respect to the effect on growth of education and of the distribution of education: education accumulation, along with capital accumulation, is good for growth $-\mathrm{a}$ result now taken for granted (columns 2 and 3). The strong positive effect exerted on growth by human capital accumulation, as reflected in the average years of education of the labour force, is consistent with the theory referred to in the introduction, as well as with microeconomic evidence that better-educated workers earn higher incomes and, particularly in the case of women, are more effective in household production of children's good health and schooling. The positive effect of a country's level of education at the beginning of a period on growth during the subsequent period is now a commonplace and highly 
robust result in virtually all cross-country studies of growth (Barro and Sala-i-Martin, 1995; Levine and Renelt, 1992). Lora and Barrera (1997) estimate that Latin America as a region could increase its growth rate by 2 percentage points a year over the next decade if, in addition to deepening structural reforms, the region were able to increase the pace of human capital accumulation for the labour force as a whole by one year over the expected level. Viewed from another angle, Birdsall, Ross and Sabot (1995) estimate that if Korea had had Brazil's level of primary and secondary education in 1960 , it would have grown by 0.56 percentage points less per year over the next 25 years, and Korea's resulting per capita GDP for 1985 would have been $12 \%$ lower than it actually was.

In addition, and controlling for the level of education, the degree of inequality in the distribution of education has a strong and robust negative effect on growth (columns 2 and 3). The variable measuring the distribution of education is highly robust, its negative effect operates independently not only of the education level variable, but also of the positive effect of trade openness and the negative effect of natural resource endowment.

It should be noted that when the asset distribution variables are included, the negative effect of income inequality on growth loses statistical significance (columns 2 and 3 versus column $\mathrm{l}$ ); the widely reported negative effect (Birdsall, Ross and Sabot, 1995; Alesina and Rodrik, 1994; Persson and Tabellini, 1994) apparently reflects differences in a fundamental element of economic structure, namely the access of different groups to productive assets.

In columns 4 to 6 of table 2, the effect of the initial distributions of income and assets on the income growth of the poor is assessed. The elasticity of income growth of the poor with respect to overall growth is well above one (column l), confirming the logic of the argument that economic growth is a key to poverty reduction. Income growth of the poor also depends heavily upon capital accumulation (columns 2 and 3). Most interestingly, initial inequalities in the distribution of land and of human capital have a clear negative effect on the income growth of the poor, by magnitudes twice those of their effects on average

\footnotetext{
${ }^{8}$ In these regressions, the standard deviation of years of education of adults aged 25 years and older is used as a measure of the distribution of education.
}

FIGURE 6

Latin America: Impact of inequality on poverty, 1970-1995

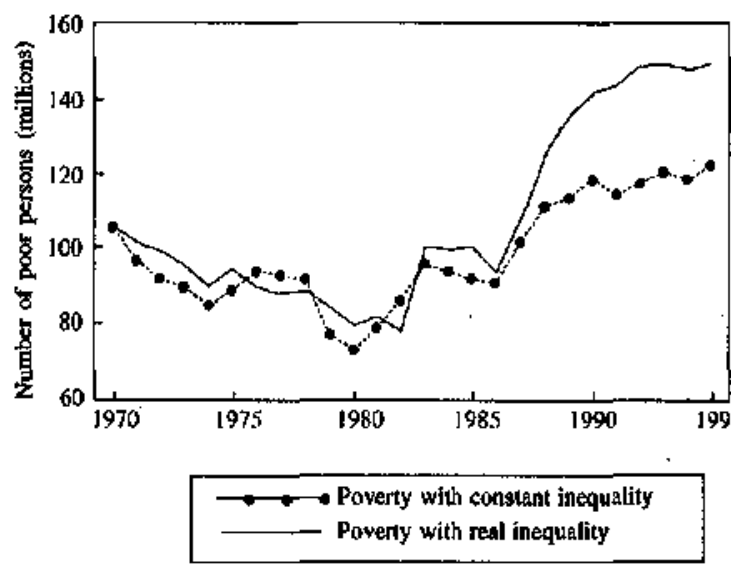

Source: N. Birdsall and J. L. Londofio, Asset inequality matters: An assessment of the World Bank's approach to poverty reduction, The American Economic Review, vol. 87, No. 2, Nashville, TN, American Economic Association, 1997.

income growth (column 2). An unequal distribution of assets, especially of human capital, affects income growth of the poor disproportionately; better distribution of assets would reduce poverty both directly and indirectly, by enhancing average growth.

Making this point with aggregate economic indicators, Birdsall and Londoño (1997) show that, if the economies of Latin America had maintained the same income distribution throughout the $1980 \mathrm{~s}$ as in 1970 , the increase in poverty over the years 1983 to 1995 would have been smaller by almost half (figure 6). But the low growth and macroeconomic instability of the 1980s harmed the poor more than others and exacerbated an already poor distribution of assets and income. These results are consistent with a view of the world in which opportunities matter. The poor, without assets, cannot take advantage of opportunities to be productive. In economies where a substantial portion of the population is without human capital, and thus without a critical productive asset, only a part of the population can exploit the growth process. The engine of growth is small, and may be periodically stalled by populist turnarounds. Driven by the increasing productivity of the initially poor, the East Asian countries, which began the postwar period with relatively low asset inequality, were able to grow at high and sustained rates over more than three decades. In contrast, most countries of Latin 
FGURE 7

Selected reglons: Giobal growth factors

(Contribution 10 variations in $G D P$, percentages)

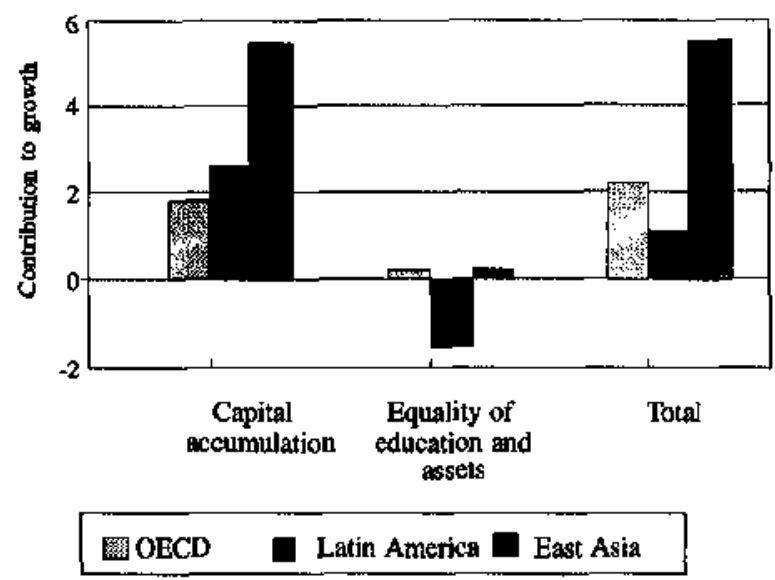

Source: Inter-American Development Bank.

America, with greater inequality of assets and presumably fewer opportunities for the poor, grew less (figure 7). The results of table 2 and the aggregate indicators summarized above point to a straightforwand if disturbing conclusion: low and unequal accumulation of human capital in Latin America has slowed aggregate economic growth and has inhibited poverty reduction.

\section{Effects on Income inequality}

A second effect of low and unequal accumulation is Latin America's persistently high income inequality.

Latin America has a Gini coefficient (about 0.50 for the region as a whole) which is approximately 15 points above the average for the rest of the world; in 1995 , the wealthiest $20 \%$ of the population was receiving $58 \%$ of the total income: i.e., 12 times the income of the poorest $40 \%$ and 19 times that of the poorest $20 \%$ of the people. The income of the poorest $40 \%$ of the population is some $20 \%$ lower than it would be with a typical pattern of income distribution. And the number of poor people, which currently stands at between 140 and 150 million individuals with daily eamings of less than US\$2, could be a third lower than it is (Londoño and Székely, 1997).

Londono and Székely (1997) show that in the world as a whole, intra-country income inequality
FIOURE 8

Latin America: Expdanation of exceselve inequality of this reglon compared with world average (Broken down by composition, level and distribution of assets

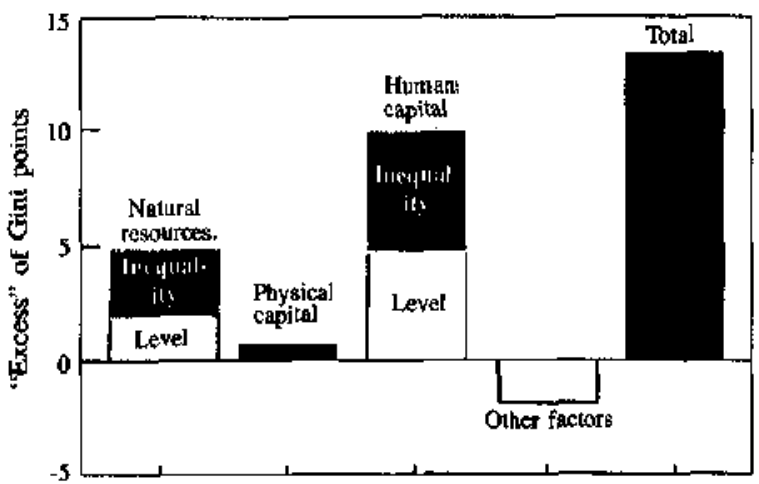

Source: J. L. Londonto and M. Székely, Distributtonal surprises after a decade of reforms: Latin America in the nineties, in $\mathrm{R}$. Hausman and E. Lora (eds.), Latin America after a Decade of Reforms: What comes next?, Washington, D. C., IDB, 1997.

can be reasonably explained by the relative abundance of factors of production such as land and physical and human capital, and by their distribution. As figure 8 shows, lower physical capital accumulation is not the culprit in the case of Latin America. Rather, the relative abundance of natural resources and a concentration of land ownership which is the highest in the world account for a substantial portion of Latin America's excessive inequality, and the low level of education (human capital) of Latin American workers and the enormous inequality in educational assets play an even larger role in explaining this.

The effect of low and unequal education on income inequality does not come as a surprise. Where a relatively small proportion of the total population completes secondary or higher education, public investment in education has generally been viewed as a mechanism to reduce poverty and inequality, given the strong evidence at the individual level that the educated earn more. At the aggregate level, however, the effect of education on poverty and inequality obviously depends on the distribution of education itself, how rapidly it spreads, and how much different groups benefit. In Latin America, only a relatively small proportion of the total population has completed secondary or higher education. These relatively few skilled workers earn a substantial wage premium due to their limited supply, thus contribut- 
ing to the overall high income inequality (Birdsall, Ross and Sabot, 1997).

The Latin American experience stands in marked contrast to that of East Asia, where education policy has produced a large supply of skilled workers, eroding any substantial premium they might have earned above the wages of the unskilled. Kuznets's theory (that income distribu- tion will initially worsen as some workers in underdeveloped economies shift to high productivity sectors) seems to have been borne out in Latin America, partly because the limited and slow spread of educational opportunities has created a large productivity gap between a small skilled group and the rest of the population (Stallings, Birdsall and Clugage (forthcoming)),

\section{III}

\section{The reasons for Latin America's}

\section{low and unequal accumulation}

The above analysis demonstrates that low and unequal accumulation of human capital has limited Latin America's growth, particularly in the income of the poor, and has exacerbated the region's high income inequality. We argue now that, in fact, there is a vicious circle: the region's low and unequal accumulation of human capital is not only a cause of current poverty and income inequality, but also an outcome of past income inequality. Low and unequal accumulation can be explained by factors of demand and supply in the market for education. ${ }^{9}$

First, on the demand side, Latin America's large endowment of natural resources historically has limited society's demand for education. The socioeconomic arrangements which accompany large-scale agricultural production and natural resource extraction tend to be characterized by a situation where there are relatively few owners of capital and many unskilled workers (Engerman and Sokoloff, 1997). There is little demand for skilled workers, partly because natural resources tend to be complementary to capital, rather than skilled labour, in production. Perhaps as a result, governments and families in Latin America have invested little in education, seeing relatively higher returns to physical capital. A rich natural resource base in the region also minimized the need for the development of competitive non-traditional exports in the early post-war period, thus perpetuating traditional production arrangements.

${ }^{9}$ The discussion in this section and the data referred to are largely from Birdsall, Bruns and Sabot (1996).
Second, high income inequality in Latin America has implied that more households are liquidity-constrained, unable to borrow and without the resources needed to keep their children in school. Flug, Spilimbergo and Wachtenheim (1996) show that financial factors explain much of the differences in secondary schooling across countries. As shown in table 3, in 1989 Brazil and Malaysia had similar levels of per capita income. But the poorest quintile in Brazil had only about one-half the absolute income level of the poorest quintile in Malaysia. Given an income elasticity of demand for secondary education of 0.50 (a conservative figure), then if the distribution of income had been as equal in Brazil as in Malaysia, secondary enrollments among poor Brazilian children would have been more than $40 \%$ higher. There is some evidence that, among the poor, the income elasticity of demand for basic schooling exceeds 1.0 , in which case secondary enrollments among poor Brazilian children would have been more than $80 \%$ higher. One quantitative study of the effect of income inequality on schooling suggests that, of the 27 percentage point secondary school enrollment rate gap between Brazil and Korea in the 1970s, more than 20 percentage points can be attributed to Brazil's greater income inequality and resultant lower enrollment of poor children (Williamson, 1993).

Third, household demand for education is not only a function of household income and household access to borrowing. It is also a function of expected returns to the family from schooling, in the form of higher future income for educated children. Two different public policies have systematically reduced 
TAELE 3

Absolule incoms share of lowest quintile

\begin{tabular}{lccc}
\hline Country & $\begin{array}{c}\text { GNP per capita } \\
\text { (US \$, PPP adjusted) }\end{array}$ & $\begin{array}{c}\text { Income share of bottom } \\
20 \% \text { of households (\%) }\end{array}$ & $\begin{array}{c}\text { Per capita income of bottom } \\
20 \% \text { of households (US \$) }\end{array}$ \\
\hline Malaysia, 1989 & 4674 & 4.6 & 1075 \\
Braxil, 1989 & 4271 & 2.4 & 513 \\
\hline
\end{tabular}

Source: For GNP: R. Summers and A. Heston, The Penn World Tables, Mark 5.6, Philadelphia, PA, University of Pennsylvania, Department of Economics, 1995; for income share data: K. Deininger and L. Squire, A new data set measuring income inexuality, The World Bank Economic Review, vol. 10, No. 3, Washington, D. C., World Bank, 1996.

the demand for basic education among the poor by reducing its expected returns.

First, economic strategies have consistently penalized labour, reducing its return and discouraging investment in education. Post-war Latin American governments pursued import substitution industrialization (IS1) policies in an attempt to shift away from the export of primary commodities and to promote local manufacturing. These ISt policies resulted in large subsidies and protection for the owners of capital but did not promote the demand for labour (Schiff and Valdés, 1992). The result was that increased profits accrued to the owners of capital, while the real wages of the unskilled workforce grew much less. Relatively low wage growth among workers, connbined with high returns to capital, did nothing to encourage demand for basic education among the poor. In the last decade, most countries of the region have dismantled these policies in pursuit of open market growth strategies. In some cases, however, a justifiable concern with reducing inflation has meant that high interest rates were needed to sustain exchange rates; this has penalized job creation in the small and medium-sized enterprise sector, and has diminished exports that are often labour-intensive.

Additionally, in parts of Latin America there has been labour market discrimination against certain ethnic, linguistic or racial groups who also tend to be poor. This discrimination has reduced the expected renurns to education among these groups and thus reduced the demand for education among the poor even further.

The second problem has been educational policy itself. The low and declining quality of basic education in Latin America -an outcome of inefficient public spending- has reduced returns to basic schooling in the region, especially for poor households whose children are most likely to attend the lowest-quality schools. The high repetition and dropout rates in Latin America, especially among the poor, are a sad testimony to parents' initial efforts to enroll children and to their subsequent growing discouragement as low quality and low achievement produce limited learning and thus limited expected economic returns."

In short, expected returns to education are a function of parents' assessment of the future labour market for their children. Where demand for labour is low (and capital is subsidized directly or indirectly), where schooling is of poor quality, and where there may be discrimination in the labour market against some groups who also tend to be poor, low expected returns to schooling will reduce the household demand for education.

At the same time, the supply of education in Latin America has itself been affected by the region's high income inequality." When the distribution of income is highly unequal, provision of subsidized basic education to a large segment of the school-age population implies a relatively large tax burden on the rich, which high-income families are likely to resist. One result can be the underfunding of education -and the decline in quality described above. A second result can be the channeling of public subsidies to higher education, where the children of the rich are more likely to be the beneficiaries. In fact, as shown in table 4 , the share of public spending on education in Latin America that is allocated to higher education has tended to be high: more than $20 \%$ on average, compared with $15 \%$ on average in East Asia. Venezuela and Korea are extreme examples in this respect.

\footnotetext{
10 The roots of low-quality basic education and its effects on the poor are discussed fully for Brazil in Birdsall, Bruns and Sabot (1996) and for Latin America in. Birdsall and Sabot (eds.), (1996).

11 Latin America spends as much on education, as a percentage of GNP, as other developing regions with similar levels of per capita income. But the fact that growth has lagged in Latin America means that education budgets have been smaller in absolute terms. In addition, higher binh rates in Latin America mean that the same percentage of GNP spending translates into lower spending per child (Birdsall and Sabot (eds.), 1996).
} 
While in the early 1990 s Venezuela allocated $35 \%$ of its public education budget to higher education, Korea allocated just $8 \%$ of its budget to post-secondary schooling. Public expenditure on education as a percentage of GNP was actually higher in Venezuela (5.1\%) than in Korea $(4.5 \%)$. However, after subtracting the share going to higher education, public expenditure available for basic education, as a percentage of GNP, was considerably higher in Korea (3.6\%) than in Venezuela (1.3\%) (UNDP, 1997).

By giving priority to expanding the quantity of education and improving the quality at the base of the educational pyramid, East Asian governments bave stimulated the demand for higher education, while relying to a large extent on the private sector to satisfy that demand. In Latin America, government subsidies have disproportionately benefited high-income families whose children are much more likely to attend university. At the same time, low public funding of secondary education has resulted in poorly qualified children from low-income backgrounds being forced into private universities or entirely out of the education system at higher levels. Underfunding of education has meant that the guarantees of universal primary education in Latin America have become false entitlements for the poor: the education available to them has been of such poor quality as to make it of little real benefit.

In summary, the relatively poor growth performance of Latin America, the persistence of income inequality, and the difficulties of reducing poverty cannot be separated from the region's troubling record of limited and unequal access to education. In a series of vicious cycles, historically high levels of asset and income inequality have generated an economic and political environment that severely limits
TABLE 4

Budget allocated to higher educalion, 1990-1994

\begin{tabular}{|c|c|}
\hline & $\begin{array}{l}\text { Percentage of overall } \\
\text { education budget }\end{array}$ \\
\hline \multicolumn{2}{|l|}{ East Asia } \\
\hline Majaysia & 17 \\
\hline Thailand & 17 \\
\hline Indonesja & 18 \\
\hline South Korea & 8 \\
\hline \multirow[t]{2}{*}{ Average (simple) } & 15 \\
\hline & $\vdots$ \\
\hline \multicolumn{2}{|l|}{ Latin America } \\
\hline Argentina & 17 \\
\hline Brazil & 26 \\
\hline Chile & 20 \\
\hline Colombia & 17 \\
\hline Costa Rica & 31 \\
\hline Dominican Republic & 11 \\
\hline Ecuador & 23 \\
\hline Honciuras & 20 \\
\hline Mexico & 14 \\
\hline Uruguay & 25 \\
\hline Venezueja & 35 \\
\hline Average (simple) & 22 \\
\hline
\end{tabular}

Source: United Nations Development Programme (UNDP), Human Development Report 1997, Santafé de Bogalá, Tercer Mundo Editores, 1997.

the opportunities of the poor. With few opportunities for education despite reasonable government spending, and without other productive assets, the poor are condemned to low-productivity work, low household income, and a new round of limited access to education. The region's societies also suffer as a whole, since educational progress and the accumulation of assets are limited to the non-poor, reducing average growth levels and perpetuating inequality.

\section{IV}

\section{Conclusions and reflections}

This article began with a critique, at least in terms of policy guidance, of current endogenous growth models -which emphasize education but fail to consider the relevance of household demand for education, the effects of the distribution of education, and the institutional problem of delivering education, especially to the poor. The discussion highights the relevance in Latin America of the demand of the poor for schooling. inhibited for many decades by economic policies biased against labour, and the distribution of human capital, with unequal access of the poor to schooling slowing the accumulation process. It also emphasizes that Latin America's resulting poor record of limited and unequal access to human capital is linked to the region's poor growth performance, the persistence of high income inequality, and the difficulties of reduc- 
ing poverty. Of particular concern are data which suggest that the distribution of education has seen little if any improvement over the last three decades.

The opening section of this article provides evidence that low and unequal accumulation of human capital has not only slowed aggregate growth in Latin America but bas also hindered poverty reduction and has contributed to the persistence of the world's highest levels of income inequality. The implication is clear -that there is great untapped potential for faster growth in the region. The growth process could benefit from major productivity increases among the poor, if they are provided with access to education. More education, and in particular education that is more equal (i.e., that reaches the poor), could accelerate the growth process and simultaneously reduce inequality.

The article then goes on to argue that, in Latin America, the low accumulation of human capital and its unequal distribution are partly rooted in longstanding inequality in terms of assets (including human capital itself) and income. Such a historic legacy is difficult to alter in the short run. But low and unequal accumulation can also be explained by the economic policies that dominated the region for decades. Closed economies that protected capital and relied heavily on natural resource exports discouraged demand for education in the poor households of Latin America, by discouraging demand for labour, the poor's major asset, and for skilled labour, where lies the poor's greatest potential for income growth.

The fact is that inequality of access has been embedded in an approach to social service delivery that encourages exclusion, segmentation and inefficiencies. Traditional vertical, bureaucratic systems for organizing schooling and other services have been inefficient and have failed to serve the poor. The altemative model of private, market-led delivery has performed no better: the competition it provides in a few countries has simply left out all those unable to pay.

However, there are grounds for optimism. Economic reforms of the last decade in most countries of the region are eliminating the biases against labour typical of protected economies, and they are bringing the macroeconomic stability that is vital' for private sector investment. This is setting the stage for increased household demand for schooling and increased interest of the business sector in a skilled labour force necessary to maintain competitiveness in open economies. These forces have created an impetus for education reform in the region and renewed interest among policy-makers in new approaches to the delivery of education, as well as of health and other public services. In some countries, alternative designs of social service delivery have begun to be applied that promote competition among both private and public suppliers, enhance consumer voice and choice, and ensure that the poor, via fair rules of access, vouchers and other demand subsidies, are fully integrated as consumers into the system. These reforms are showing that efficiency and fairness can be achieved simultaneously. ${ }^{12}$

Trade-offs are not inevitable in the development process: many are the outcome of poor policy decisions and weak institutions. A focus on equal access for the poor to the services that generate human capital -in other words, a reversal of the trickle-down approach-can bring more growth and improved equity to Latin America's economies and peoples.

(Original: English)

\section{Bibliography}

Alesina, A and D. Rodrik (1994): Distributive politics and economic growth: A critical survey of the recent literature, The Quarterly Joumal of Economics, vol. CDX, pp. 465-490, May.

Barro, R.J. (1991): Economic growth in a cross section of countries, The Quarterly Journal of Economics, vol. CVx, pp. 407-443, May.

Baro, R.J. and J. Lee (1993): International Comparisons of Educational Attainment, Washington, D. C., World Bank.

Barro, R. J. and X. Sala-i-Martin (1995): Economic Growth, New York, McGraw-Hill.
Birdsall, N. (1998): Education: The people's asset (paper prepared for the conference on Asset Distribution, Poverty and Economic Growth, Brasilia, 14-17 July). (http://www. worldbank.org/landpolicy/brazil/papers. htm.

Bircisall, N., B. Bruns and R. Sabot (1996): Education in Brazil: Playing a bad hand badly, in N. Birdsals and

12 See Birdsall and Londoño, 1998, for a discussion of alternative approaches to social service delivery. 
R. Sabot (eds.), Opportunity Forgone: Education in Brazil, Washington, D.C., The Johns Hopkins University Press.

Birdsall, N. and J. L. Londoño (1997): Asset inequality matters: An assessment of the World Bank's approach to poverty reduction, The American Economic Review, vol. 87, No. 2, Nashville, TN, American Economic Association.

(1998): No trade-off: Efficient growth via more equal human capital accumulation in Latin America, in $\mathbf{N}$. Birdsall, C. Graham and R. Sabot (eds.), Beyond Trade-Offs: Market Reforms and Equitable Growth in Latin America, Washington, D. C., The Brookings Institution/IDB.

Birdsall, N., D. Ross and R. Sabot (1995): Inequality and growth reconsidered: Lessons from East Asia, The World Bank Economic Review, vol. 9, No. 3, Washington, D.C., World Bank.

- (1997): Education, growth and inequality, in N. Birdsall and F. Jaspersen (eds.), Pathways to Growth: Latin America and East Asia, Washington, D.C., IDB,

Birdsall, N. and R. Sabot (eds.) (1996): Opportunity Forgone: Education in Brazil, Washington, D. C., The Johns Hopkins University Press.

Deininger, K. and L. Squire (1996): A new data set measuring income inequality, The World Bank Economic Review, vol. 10, No. 3, Washington, D. C., World Bank.

Engerman, S.L. and K.L. Sokoloff (1997): Factor endowments, institutions and differential paths of growth among New World economies: A view from economic historians of the United States, in S. Haber (ed.), How Latin America Fell Behind: Essays on the Economic History of Brazil and Mexico, 1800-19/4, Stanford, CA, Stanford University Press.

Flug, K., A. Spilimbergo and E. Wachtenheim (1996): Investment in Education: Do Economic Volatility and Credit Constraints Matter?, Office of the Chief Economist working paper series, No. 301, Washington, D. C., IDB.

IDB (Inter-American Development Bank) (1996): Economic and Social Progress in Latin America, Washington, D. C.

Levine, R. and D. Renelt (1992): A sensitivity analysis of cross-country growth regressions, The American Economic Review, vol. 82, No. 2, Nashville, TN, American Economic Association.

Londoño, J.L. and M. Székely (1997); Distributional surprises after a decade of reforms: Latin America in the nineties, in R. Hausman and E. Lora (eds.), Latin
America After a Decade of Reforms: What Comes Next?, Washington, D. C., IDB.

Lora, B. and F. Barrera (1997): A decade of structural reforms in Latin America: Growth, productivity and investments are not what they used to be, in $\mathbf{R}$. Hausman and E. Lora (eds.), Latin America After a Decade of Reforms: What Comes Next?, Washington, D. C., IDB.

Persson, T. and G. Tabellini (1994): Is inequality harmful for growth?, The American Economic Review, vol. 84, No. 3, Nashville, TN, American Economic Association.

Schiff, M. and A. Valdes (1992): The Political Economy of Agricultural Pricing Policy. Volume 4: A Synthesis of the Economics in Developing Countries, Baltimore, MD, Johns Hopkins University Press.

Schiefelbein, E. (1995): Characteristics of the Teaching Profession and the Quality of Education in Latin America. Bulletin: The major project of education in Latin America and the Caribbean, No. 34, Santiago, Chile, United Nations Educational, Scientific and Cultural Organization (UNESCO).

Schultz, T. P. (1988): Education investment and returns, in H. B. Chenery and T.N. Srinivasan (eds.): Handbook of Development Economics, Amsterdam, North-Holland Publishing Company.

Stallings, B., N. Birdsall and J. Clugage (forthcoming): Growth and inequality: Do regional patrerns redeem Kuznets?, in A. Solimano (ed.), Distributive Justice and Economic Development: The Experience of Chile and Developing Countries, Ann Arbor, MI, University of Michigan Press.

Summers, R. and A. Heston (1995): The Penn World Tables, Mark 5.6., Philadelphia, PA., University of Pennsylvania, Department of Economics.

UNESCO (United Nations Educational, Scientific and Cultural Organization) (several years): Statistical Yearbook, New York, Beman Press.

UNDP (United Nations Development Programme) (1997): Human Development Report 1997, New York, Oxford University Press.

Williamson, 3. (1993): Human capital deepening, inequality and demographic events along the Asia-Pacific rim, in N. Ogawa, G. W. Jones and J. Williamson (eds.), Human Resources in Development along the Asia-Pacific Rim, Singapore, Oxford University Press.

World Bank (several years): World Development Report, Washington, D. C. 